\title{
Hooded Vultures at an abattoir in Kigali, Rwanda.
}

\section{Bonnie Friedman}

Johannesburg, South Africa

Correspondence: bonnie.friedman.home@gmail.com
In May 2021, I had occasion to visit an abattoir in Kigali, Rwanda, in the suburb of Nyabugogo at $1^{\circ} 56 \mathrm{~S}, 30^{\circ} 02^{\prime} \mathrm{E}$, in the north-west corner of the city. The abattoir is managed by SABAN (Societé d'Abattoir de Nyagature) and is surrounded by a wall and occupies an area of approximately 3 ha (Muhirwa et al. 2010). On 15 May, at 14h00, during a brief visit, there were vultures circling overhead as well as some feeding on a pile of rumen contents (Figure 1). I estimated there were approximately 50 Hooded Vultures Necrosyrtes monachus in a mixed group of birds that included a few each of Yellowbilled Stork Mycteria ibis, African Sacred Ibis Threskiornis aethiopicus, Hadada Ibis Bostrychia hagedash, Yellow-billed Kite Milvus aegyptius and Pied Crow Corvus albus, mostly in the air. On a similarly quick visit on 22 May, also at 14h00, I saw approximately 30 Hooded Vultures, with up to ten individuals (adults and immatures) pecking around a pile of rumen contents. It is noteworthy that there were no Hooded Vultures seen outside the abattoir, perhaps due to there being very little litter or waste allowed to accumulate in the town due to strict waste management legislation that includes a ban on single use plastics (Kabera, Wilson \& Nishimwe 2019).

In their book (2011), Jean Pierre and Gaël Ruboneka Vande weghe note the occurrence of six species of vulture in the country, mostly on the eastern savannah side. They stated that the Hooded Vulture occurred over one-half of the country but was seriously affected by poisoning campaigns aimed at controlling mammalian carnivores in the 1980s and 1990s. The authors note that the species could be seen at "slaughterhouses" and "around Kigali". My observations confirm their continued use of slaughterhouses, but perhaps the relatively recent improvements to waste management have reduced foraging opportunities across the wider city. Visits to other abattoirs in the city may be informative.

\section{Acknowledgements}

I thank Peter Mundy for helping me to produce this note.

\section{References}

Kabera, T., Wilson, D.C., \& Nishimwe, H. 2019. Benchmarking performance of solid waste management and recycling systems in East Africa: Comparing Kigali Rwanda with other major cities. Waste Management \& Research 37(1_suppl): 58-72.

Muhirwa, D., Nhapi, I., Wali, U.G., Banadda, N., Kashaigli, J.J. \& Kimwaga, R. (2010). Characterization of abattoir wastewater of Kigali, Rwanda. International Journal of Ecology \& Development 16(S10): 30-46.

Vande weghe, J.P. \& Vande weghe, G.R. (2011). Birds in Rwanda an atlas and handbook. Rwanda Development Board, Kigali. 


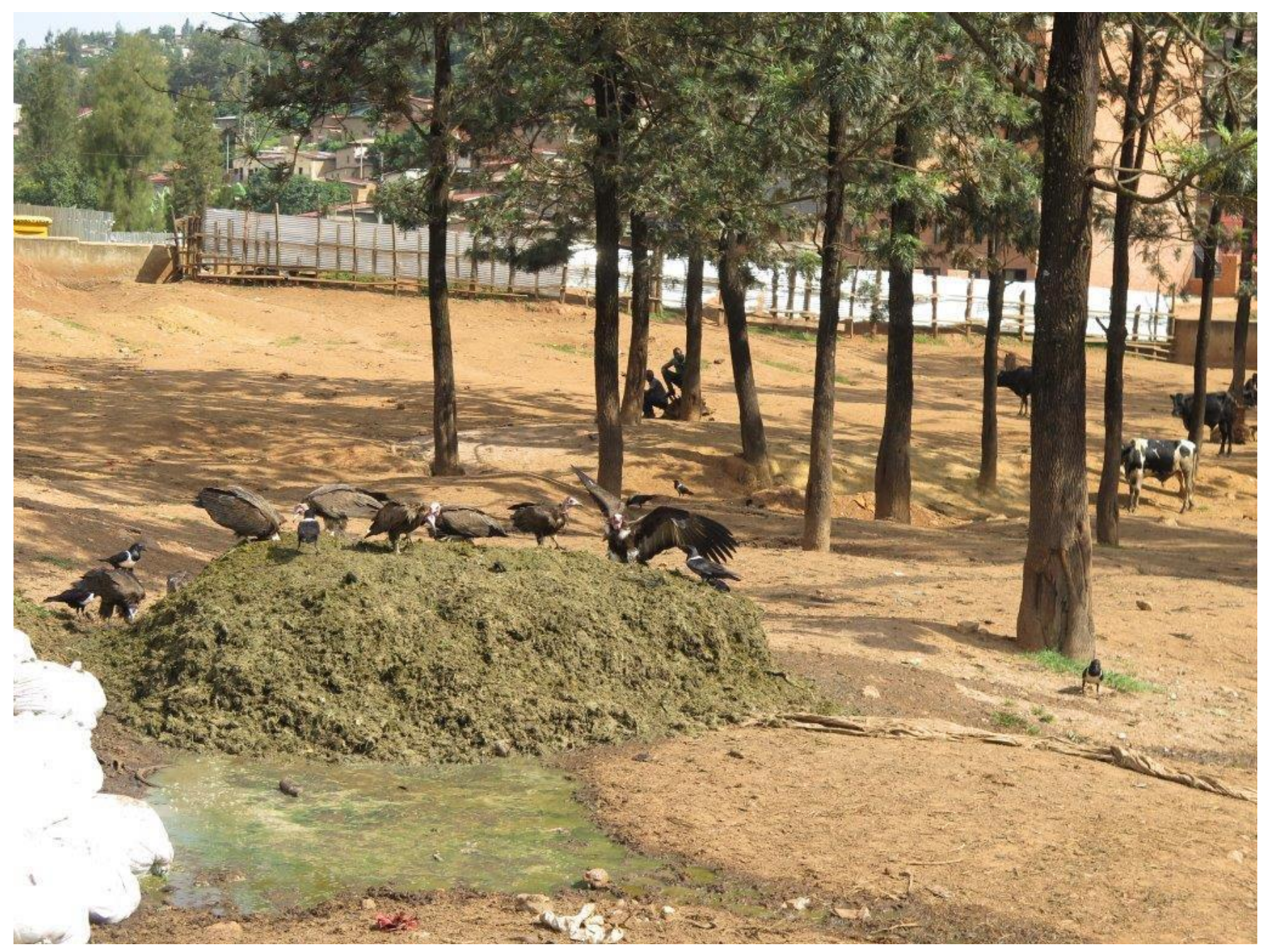

Figure 1: Part of a group of approximately 50 Hooded Vultures observed feeding on rumen content with other avian scavengers at an abattoir in the Nyabugogo suburb of Kigali, Rwanda, on 15 May 2021.

Photograph: Penny Hoets. 